\title{
Antimicrobial Activity of Sonneratia ovata Backer
}

\author{
Laili Khumaidah, Adi Setyo Purnomo, Sri Fatmawati* \\ Department of Chemistry, Faculty of Science, Institut Teknologi Sepuluh Nopember, Kampus ITS Sukolilo, Surabaya, Indonesia
}

\section{ARTICLE INFO}

Article history:

Received July 18, 2018

Received in revised form October 18, 2018

Accepted March 1, 2019

\section{KEYWORDS:}

Sonneratia ovata,

antimicrobial,

stigmasterol

\begin{abstract}
Sonneratia, a genus of mangroves from family Lythraceae, is reported for number of high biological activity including antimicrobial. Sonneratia ovata Backer is one of the species which traditionally used by Indonesian people for the treatment of some diseases. In this research, the investigation about biological activity of $S$. ovata Backer as anti-microbial has been performed. The methanol extract of $S$. ovata Backer is highly potential as antimicrobial against gram positive bacteria, $S$. aureus, with $\mathrm{IC}_{50}$ value of $7.7 \mu \mathrm{g} / \mathrm{ml}$ which is higher than of Ampicillin as positive control with $\mathrm{IC}_{50}$ value of $37.8 \mu \mathrm{g} / \mathrm{ml}$. Furthermore, stigmasterol one of the major compound of $S$. ovata Backer has been isolated from the methanol extract of the stem bark of $S$. ovata Backer. Therefore, $S$. ovata Backer is proven to have high activity as antimicrobial, and highly potential to be a new source of antimicrobial agent.
\end{abstract}

\section{Introduction}

Pathogenic microbes are one of the causes of number of disease in human, animals, or plants (Purnomo et al. 2018). Pathogenic microbes are consist of some kinds of microorganisms, such as bacteria, fungus, and algae. Some diseases caused by pathogenic microbes, specially bacteria are skin infection, pneumonia, endocarditis, and osteomilietis that caused by gram positive bacteria (Bush and Perez 2017). Because of the large number of newly discovered pathogens in last period, as well as the increasingly strong resistance of pathogens to antibiotics which brings pathogens become immune to some well-known antimicrobials (Putri et al. 2018; Auwaliyah et al. 2019; Ramadhania et al. 2019), therefore, many new antimicrobials are needed to inhibit the pathogens growth (Rahman et al. 2005).

Sonneratia (Lythraceae) is one of the genus of mangroves which only exist in Indomalayan area. Sonneratia consists of some species, such as $S$. caseolaris, S. alba, S. apetala, S. griffithi, S. hainanensis, S. lanceolata, and S. ovata (Mao and Foong 2013). Its high ability to adapt in extreme environment with high temperature and salinity, strong wind, and muddy anaerobic soil makes Sonneratia become rich of secondary metabolites with unique biological activity and high of medical potential. Traditionally, Sonneratia

\footnotetext{
* Corresponding Author

E-mail Address: fatma@chem.its.ac.id

has been used in treatment of some diseases, such as asthma, hepatitis, hemorrage, ulcer, and hemmoroid (Bandaranayake 2003). Some reports showed some medical potential of Sonneratia, such as $S$. caseolaris has strong antioxidant activity (Bunyapraphatsara 2003), while Saad et al. 2012 reported that S. alba has positive antimicrobial activity against some microorganisms (Saad et al. 2012). S. griffithi shows a high activity as antihyperglycemia (Tiwari et al. 2008 ), and S. caseolaris shows intestinal $\alpha$-glucosidase inhibitory activity (Kaewpiboon et al. 2012). One of the species of Sonneratia grows naturally in Indonesian coastline, specially in Aru Island, Maluku is S. ovata Backer. Morphology of the tree of S. ovata Backer is a columnar tree with quadrangular branches high of 7.2 meters, pale brown to grey color, thin and sharp pneumatophores. The leaves are apex obtuse but rounded at the base, glossy on the upper surface but satiny lower surface. The fruits of $S$. ovata Backer are berry-like with seeds and sized 4-6 cm (GouthamBharathi et al. 2012).

Research about bioactivity of $S$. ovata Backer have been reported (Khumaidah et al. 2018). There are several compounds have been successfully isolated from the extract of $S$. ovata Backer and examined for the activity. Four compounds were isolated by Nguyen et al. 2015. There are three new fenolic compounds; sonnerfenolic A, sonnerfenolic B, and sonnerfenolic $C$, and one cerebroside called sonnercerebroside. Sonnercerebroside showed high cytotoxic activity against MCF-7 cancer cell with $\mathrm{IC}_{50}$ value of $112.8 \pm 9.4$ $\mu \mathrm{m}$ (Nguyen et al. 2015). 
S. ovata Backer, which traditionally called Manggustang Pante, has been used as a folk medicine to treat diseases for over decades by drink the water extract of S. ovata Backer. That ethnobotanical report indicates that S. ovata Backer has high biological activity which can lead to further investigation, specially for the antimicrobial activity.

\section{Materials and Methods}

\subsection{Extraction}

The stem bark of $S$. ovata Backer was collected from Aru Islands, Maluku. The plant was dried and powdered to form a $1.5 \mathrm{~kg}$ of sample. Extraction was conducted by soaking sample in seven liters of methanol within three days at room temperature. Solvent then was evaporated to give 153 grams of methanol extract.

\subsection{Isolation}

Crude methanol extract of the stem bark of $S$. ovata Backer then was partitioned with butanol and water (1:1). The butanol phase was collected and evaporated, then was subjected to the silica gel column chromatography. Column chromatography was eluted with mixture of $n$-hexane:ethyl acetate (7:3) to gain five fractions. Thin layer chromatography was used to combine the fractions with the same profile. Fraction with one clear spot on TLC chromatogram then purified for NMR examination.

\subsection{Bacteria Preparation}

The antimicrobial assay using gram positive and negative bacteria, S. aureus, B. subtilis, E. coli, and $P$. aeruginosa. The bacteria were obtained from the collection of Microorganism Laboratory, Department of Chemistry, ITS, then were inoculated in Nutrient Broth and incubated for 24, 20,24, and 21 hours, respectively. Each of the bacteria in Nutrient Broth then was diluted until final concentration of $1 \times 10^{4} \mathrm{CFU} / \mathrm{ml}$.

\subsection{Antimicrobial Assay}

Antimicrobial assay was done by adapting method of Arias et al. 2004 with modification. A $50 \mu l$ of each of gram positive and negative bacteria with concentration of $1 \times 10^{4} \mathrm{CFU} / \mathrm{ml}$ was added to $5 \mu \mathrm{l}$ sample in 445 $\mu l$ Nutrient Broth. The mixture was then incubated for 18 hours at $37^{\circ} \mathrm{C}$. The antimicrobial activity then calculated on 96 micro-well plate at $630 \mathrm{~nm}$ using spectrophotometer. Positive and negative controls were Ampicillin and DMSO, respectively (Arias et al. 2004).

\section{Results}

\subsection{Isolation of Stigmasterol from $S$. ovata Stem Bark}

The methanol extract of the stem bark of S. ovata Backer (3 grams) was partitioned with butanol and water $(1: 1)$, two times. The butanol phase were combined and evaporated to yield 0.83 gram of crude butanol phase. The crude butanol phase then diluted in ethyl acetate and subjected to the column chromatography, with $n$-hexane:ethyl acetate (7:3) as the eluent. The fractination using column chromatography to give five fractions. The profile of the second fraction (Fraction B) was monitored using TLC with cerium sulfate as the coloring agent and yielded one clear spot with $\mathrm{Rf}$ value of 0.58 . Furthermore, TLC chromatogram profile of fraction $B$ and Stigmasterol which was already identified using $1 \mathrm{H}$ and $13 \mathrm{C}-\mathrm{NMR}$, were examined. For $1 \mathrm{H}-\mathrm{NMR}$ (400 MHz, CDCl3) $\delta$ (ppm): 0.91 (s, 3H), 0.98 (s, 3H), $1.06(\mathrm{~s}, 3 \mathrm{H}), 1.19$ (s, 3H), 1.23 (s, 3H), 3.20 (tdd, OH, $\mathrm{H}-3), 4.14(\mathrm{~s}, 1 \mathrm{H}), 4.57(\mathrm{~s}, 1 \mathrm{H})$, and $5.24(\mathrm{~m}, 1 \mathrm{H}, \mathrm{H}-6)$ and 13C-NMR (400 MHz, CDCl3) $\delta$ (ppm): 71.95 (C3), 129.40 (C5), 121.87 (C6), 29.08 (C16), 140.88 (C22), 138.47 (C23), 32.04 (C25), and 12.41 (C29).

\subsection{Antimicrobial Assay}

Screening of inhibition against microbial by extract of $S$. ovata Backer showed a significant data where $S$. ovata Backer strongly inhibits growth of $S$. aureus bacteria and slightly inhibits $B$. subtilis bacteria. In addition, extract of $S$. ovata Backer is not active against E. coli and $P$. aeruginosa (Table 1 ). This result indicates a high potential activity of $S$. ovata Backer against $S$. aureus bacteria and lead to the calculation of $\mathrm{IC}_{50}$ value presented in Figure 1 and summarized in Table 2. On the other side, Stigmasterol as a major compound of $S$. ovata Backer has been previously reported its minimum inhibitory concentration against $S$. aureus and $E$. coli bacteria.

Table 1. Inhibition rate (\%) of extract of S. Ovata Backer

\begin{tabular}{lcccc}
\hline \multirow{2}{*}{\multicolumn{1}{c}{ Sample }} & \multicolumn{3}{c}{ Inhibition (\%) ${ }^{1}$ against bacteria of } \\
\cline { 2 - 5 } & S. aureus & B. subtilis & E. coli & P. aeruginosa \\
\hline Extract of S. ovata Backer & $155.43 \pm 13.9$ & $23.8 \pm 11.56$ & NA $^{2}$ & NA $^{2}$ \\
Positive control (Ampicillin) & $109.13 \pm 4.83$ & $86.91 \pm 15.8$ & $912.32 \pm 1461.9$ & $136.8 \pm 54.9$ \\
\hline
\end{tabular}




\section{Discussion}

The TLC chromatogram profile comparation between fraction B of S. ovata Backer and Stigmasterol standard shows the same $R_{\mathrm{f}}$ value of 0.58 . This result shows that the fraction B isolated from S. ovata Backer is Stigmasterol, which was already identified using ${ }^{13} \mathrm{C}$ NMR (Table 2). The ${ }^{13} \mathrm{C}$ NMR spectrum showed signals on the chemical shift of $140.9,138.5,129.4$, and 121.9 $\mathrm{ppm}$ as groups of alkene. Signal $71.9 \mathrm{ppm}$ for $-\mathrm{C}-\mathrm{OH}$ (C-3), $31.7 \mathrm{ppm}$ for - $\mathrm{CH}-$ (C-25), $29.1 \mathrm{ppm}$ for - $\mathrm{CH} 2$ (C16), and $12.4 \mathrm{ppm}$ for carbon methyl (C-29). From the NMR data above and comparation to the previously NMR data identified by Nayak et al. 2015 it is clarified that the compound is Stigmasterol (Figure 2) (Nayak et al. 2015).

Screening of inhibition against microbial by extract of S. ovata Backer showed a significant data. Extract of S. ovata Backer strongly inhibits growth of $S$. aureus bacteria at $155.43 \pm 13.95 \%$, while Ampicillin as the positive control only inhibits at $109.13 \pm 4.83 \%$. However, the inhibition rate of extract $S$. ovata Backer against $B$. subtilis bacteria is as low as $23.8 \pm 11.56 \%$ compared to Ampicillin which strongly inhibits at $86.91 \pm 15.8 \%$. On the other side, extract of $S$. ovata Backer does not inhibit the gram negative bacteria at all, both against $E$. coli or $P$. aeruginosa. This result indicates a high potential

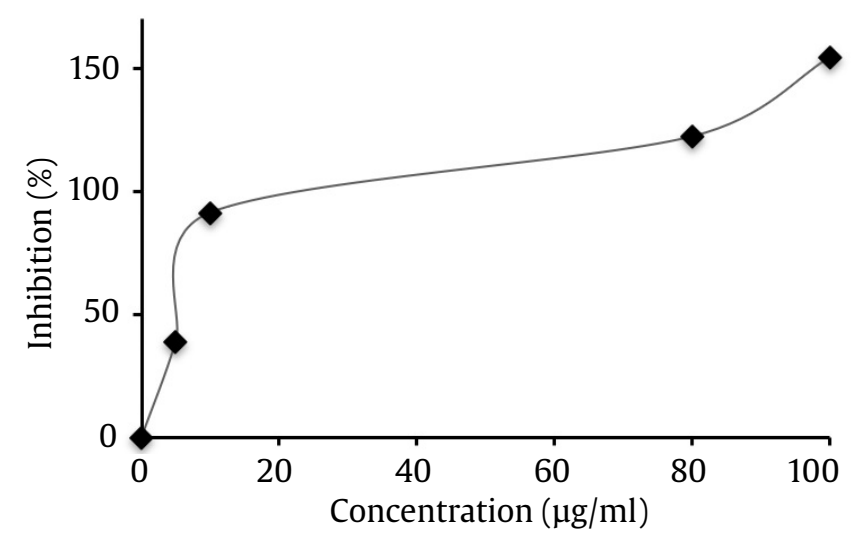

Figure 1. Antimicrobial activity of $S$. ovata extract against S. aureus activity of S. ovata Backer against S. aureus bacteria and lead to the calculation of $\mathrm{IC}_{50}$ value. Extract of $S$. ovata Backer shows $\mathrm{IC}_{50}$ value of $7.7 \mu \mathrm{g} / \mathrm{ml}$ and Ampicillin shows $\mathrm{IC}_{50}$ value of $37.8 \mu \mathrm{g} / \mathrm{ml}$. The significant result of the inhibitory activity of $S$. ovata Backer against $S$. aureus reveals the fact that $S$. ovata Backer has extremely stronger activity than the common antibacteria, Ampicillin.

The inhibition of gram positive bacteria, S. aureus is estimated to be associated with the increasing permeability of bacteria membrane (Greenway and Dyke 1979). Commonly, long chain fatty acid inhibit gram positive bacteria better than gram negative bacteria because of the outer membrane of gram negative bacteria (Nieman 1954). Gram negative bacteria has the outer membrane that prevents fatty acid to reach the inner sitoplasm, while there is no outer membrane owned by gram positive bacteria. The previous report showed that long chain fatty acids are bactericidal for the gram positive bacteria that causing lysis of protoplasts which stabilized osmotically, leakage of absorbing material and protein, both from bacteria and protoplasts, and inhibition in oxygen and amino acid uptake (Galbraith et al. 1971).

Stigmasterol, which as major compound of $S$. ovata Backer has also been tested previously for its inhibitory activity against some bacteria. Bacteria

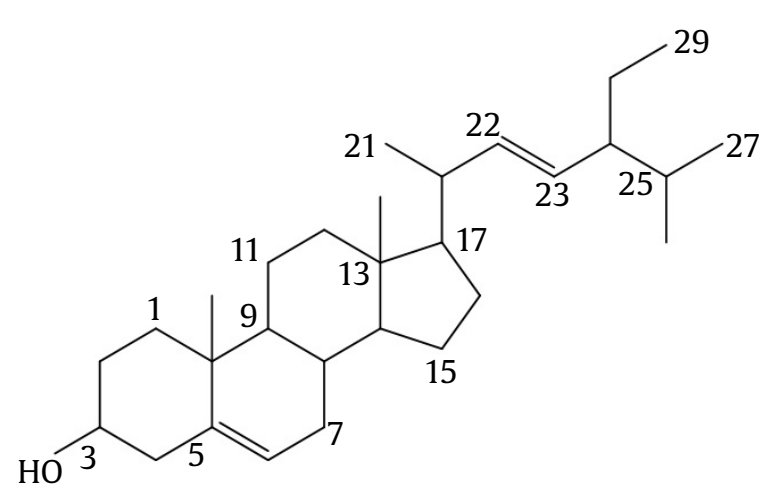

Figure 2. Chemical structure of Stigmasterol

Table $2 . \mathrm{IC}_{50}$ value of extract of $S$. ovata Backer

\begin{tabular}{lcccc}
\hline \multirow{2}{*}{ Sample } & \multicolumn{4}{c}{$\mathrm{IC}_{50}$ value $(\mu \mathrm{\mu g} / \mathrm{ml})$ against bacteria of } \\
\cline { 2 - 5 } & S. aureus & B. subtilis & E. coli & P. aeruginosa \\
\hline Extract of S. ovata Backer & 7.7 & $\mathrm{NT}^{2}$ & $\mathrm{NA}^{1}$ & $\mathrm{NA}^{1}$ \\
Positive control (Ampicillin) & 37.8 & $\mathrm{NT}^{2}$ & 10.28 & $\mathrm{NT}^{2}$ \\
\hline
\end{tabular}

${ }^{1}$ NA: Not active, ${ }^{2}$ NT: Not tested 
used in the assay were both gram prositif and gram negative bacteria, $S$. aureus and $E$. coli. The minimum inhibitory concentration was determined using broth dilution method, and the MIC was defined as the lowest concentration of the compound inhibiting the visible growth of each micro-organism, resulting the MIC value of 12.5 and $25 \mu \mathrm{g} / \mathrm{ml}$ for the $S$. aureus and E. coli bacteria, respectively (Yusuf et al. 2018). This report showed that Stigmasterol is stongly inhibit both gram positive and gram negative bacteria that means Stigmasterol is potential as antimicobial agent.

\section{Conclusion}

Exract of S. ovata Backer has high biological activity as antimicrobial agent. The extract of $S$. ovata Backer is highly potential as antimicrobial against gram positive bacteria, S. aureus better than Ampicillin. Furthermore, a major compound has been isolated from the methanolic extract of the stem bark of $S$. ovata Backer and recognized as Stigmasterol. Stigmasterol has also performed a high inhibitory activity against $S$. aureus. Therefore, extract of $S$. ovata Backer is highly potential as a new antimicrobial against $S$. aureus. Further isolation from the extract of S. ovata Backer and other biological activity assay, both on extract and compounds are needed to enrich the reports of $S$. ovata Backer.

\section{Acknowledgements}

This work was supported by a grant from research project for International Research Collaboration and Scientific Publication from The Directorate of Research and Community Service, Directorate General of Strengthening Research and Development, Ministry of Research, Technology and Higher Education, Indonesia. The support of Healthy Kainama for providing samples were also acknowledged.

\section{References}

Arias ME et al. 2004. Antibacterial activity of ethanolic and aqueous extracts of Acacia aroma Gill. ex Hook et Arn. Life Sciences 75:191-202.

Auwaliyah F et al. 2019. Antioxidant and antibacterial activities of Ichaemum indicum leaves extracted using different solvents. Malaysian Journal of Fundamental and Applied Sciences 15:436-440.

Bandaranayake WM. 2003. Bioactivities, bioactive compounds and chemical constituents of mangrove plants. Wetlands Ecology and Management 10:421-452.

Bunyapraphatsara $\mathrm{N}$ et al. 2003. Pharmacological studies of plants in the mangrove forest. Thai Journal of Phytopharmacy 10:1-12.
Bush LM, Perez MT. 2017. Staphylococcal Infections. Available at:http://www.merckmanuals.com/professional/ infectious-diseases/gram-positive-cocci/staphylococcalinfections [Data accessed at October 16 2017]

Galbraith $\mathrm{H}$ et al. 1971. Antibacterial activity of long chain fatty acids and the reversal with calcium, magnesium, ergocalciferol, and cholesterol. Journal of Applied Bacteriology 34:803-813.

Goutham-Bharathi MP et al. 2012. Sonneratia ovata (Sonneratiaceae)-a new distributional record for India from Andaman and Nicobar Islands. Taiwania 57:406-409.

Greenway DLA, Dyke KGH. 1979. Mechanism of the inhibitory action of linoleic acid on the growth of Staphylococcus aureus. Journal of General Microbiology 115:233-245.

Kaewpiboon C et al. 2012. Studies of the in vitro cytotoxic, antioxidant, lipase inhibitory, and antimicrobial activities of selected Thai medicinal plants. BMC Complementary and Alternative Medicine 12:217-225.

Khumaidah L et al. 2018. In vitro antioxidant activity of Sonneratia ovata Backer extract. Research Journal of Chemistry and Environtment 22:146-150.

Mao L, Foong SY. 2013. Tracing ancestral biogeography of Sonneratia based on fossil pollen and their probable modern analogues. Palaeoworld 22:133-143.

Nayak PS et al. 2015. Isolation and characterization of stigmasterol from chlroroform fraction of aerial part of Argemone mexicana L. Int J Pharm Pharm Sci 7:25-29.

Nguyen THT et al. 2015. Chemical constituents from Sonneratia ovata Backer and their in vitro cytotoxicity and acetylcholinesterase inhibitory activities. Bioorganic and Medicinal Chemistry Letters 25:2366-2371.

Nieman C. 1954. Influence of trace amounts of fatty acid on the growth of microorganisms. Bacteriological Reviews 18:147-163.

Purnomo AS et al. 2018. Effects of bacterium Ralstonia pickettii addition on DDT biodegradation by Daedalea dickinsii. Research Journal of Chemistry and Environtment 22:151156.

Putri DA et al. 2018. Antioxidant and antibacterial activities of Ananas comosus peel extracts. Malaysian Journal of Fundamental and Applied Sciences 14:307-311.

Rahman A et al. 2005. Bioassay Techniques for Drug Development. Holland:Harwood Academic Publishers.

Ramadhania NR et al. 2019. Anti-oxidant and anti-bacterial activities of Authurium plowmanii leaves extracts. Malaysian Hournal Fundamental and Applied Sciences 15:194-199.

Saad S et al. 2012. In vitro antimicrobial activity of mangrove plant Sonneratia alba. Asian Pacific Journal of Tropical Biomedicine 2:427-429.

Tiwari P et al. 2008. Search for antihyperglycemic activity in few marine flora and fauna. Indian Journal of Science and Technology 1:1-5.

Yusuf AJ et al. 2018. Antimicrobial activity of stigmasterol from the stem bark of Neocarya macrophylla. Journal of Medicinal Plants For Economic Development. 2:1-5. 